\title{
THE NATO 2030 REPORT. STRATEGIC PRIORITIES OF THE ALLIANCE
}

\author{
Klára SIPOSNÉ KECSKEMÉTHY \\ National University of Public Service, Budapest, Hungary \\ siposne.kecskemethy.klara@uni-nke.hu
}

\begin{abstract}
According to the NATO 2030 report the Alliance will have to adapt to a more complex strategic environment over the next decade. In this study, we address the major strategic priorities of the report, and its recommendations for the Alliance's partnerships. NATO's partnership initiatives (Partnership for Peace, Mediterranean Dialogue, Istanbul Cooperation Initiative, Partners Across the Globe) are key tools for building cooperative security and cooperation with partners. It provides a good opportunity to review the Alliance's ability of continuous innovation and its adaptation to a changing world.
\end{abstract}

Keywords: NATO 2030 report, transatlantic bond, burden sharing, cooperative security, Berlin Partnership Package

\section{Introduction}

On April 4, 2020, the North Atlantic Treaty Organization (hereinafter referred to as the Organization, the Alliance, NATO) celebrated its 70 th anniversary. Today, it is the most successful Alliance in history, with its borders stretching from the Pacific coast of North America to the Black Sea. Nearly a billion people live in the member states, and half of the global GDP is given by these countries. From the beginning, NATO has also been a political and military alliance unifying allies behind a common strategic vision, a community of shared values, shared interests and shared destiny. The debates within the Alliance are not new, because the Organization has had to be renewed many times since its inception, both during the Cold War (1951Committee of Three; 1956-"Three Wise Men"; 1967-Harmel Report) and in the post bipolar era. It was suggested that member states should take into account the interests of other NATO members in their national policies, and the consensus reached must be validated/mainstreamed into national policies. Some of these thoughts and suggestions are echoed in the NATO 2030 report. By the second half of the 1960s, a committee was set up to investigate internal tensions and disputes within NATO. The guideline of the Harmel report entitled "The future tasks of the Alliance" [1] underlined the inseparability of the Alliance's dual system of political and military tasks. Its main objective was to create a more stable international system, which was proposed to be achieved by further expanding of the consultation system. The Alliance then adopted a new strategy, the so-called flexible response doctrine to suit the political, military and technological circumstances.

\section{Debates within NATO in the post bipolar era}

After the Cold War, it became clear that since both the Soviet Union and the 
Warsaw Pact had ceased to exist, NATO had no further raison d'être. The Alliance, which has existed for 71 years, is once again looking for a new meaning for its own existence. In the recent period, a number of internal criticisms have been made regarding the functioning of the Alliance, its operations (Yugoslav air campaign, Iraq, Afghanistan, Libyan airstrikes etc.) and the defense expenditures of the member states [2]. As early as 2011, one of the Alliance's biggest challenges was to make the most efficient use of the scarce resources available. The military capabilities of the transatlantic burdensharing and the distribution between the two continents was a topic on numerous occasions within the Alliance. US Defense Secretary Robert Gates in his speech in Brussels on June 10, 2011 was highly critical on this topic [3]. He clearly outlined the two-tier political-military alliance, in which some member states focus on the so-called "soft security" (peacekeeping, humanitarian operations) activity, while others carry out combat operations (hard combat missions). He mentioned that just five of 28 allies - the U.S., the U.K., France, Greece, and Albania - exceeded the agreed $2 \%$ of GDP spending on defense. A few years later, Robert Gates' thoughts returned. U.S. President Donald Trump has repeatedly criticized the Alliance and its member states, demanded greater financial sacrifices and called NATO "outdated" [4]. In his speech at the NATO Summit in Brussels on May 25, 2017 he made it clear that the Alliance should place greater emphasis on terrorism, migration, the Russian threat, and on the eastern and southern wings of the Alliance [5]. French President Emmanuel Macron spoke of NATO's “brain death" due to a lack of strategic coordination and leadership from the United States [6].

\section{NATO 2030 report}

The Macron statement prompted the Alliance to take immediate action. At the NATO leaders meeting in London in December 2019, the leaders of the Alliance's member states asked Jens Stoltenberg, Secretary General of NATO to initiate a comprehensive Forward-Looking Reflection Process [7]. On March 31, 2020 Jens Stoltenberg appointed experts of the Reflection Group. The group was cochaired by former German Federal Minister of Defense Thomas de Maizière and former US Assistant Secretary of State for European and Eurasian Affairs A. Wess Mitchell. The Reflection Group included John Bew (GBR), Greta Bossenmaier (CAN), Anja Dalgaard-Nielsen (DNK), Hubert Védrine (FRA), Marta Dassù (ITA), Herna Verhagen (NLD), Anna Fotyga (POL) and Tacan Ildem (TUR). In our opinion, the composition of the expert group does not reflect the changed geographical focus of the Alliance as a result of the enlargement circles of the post bipolar era, although 14 of the 30 member states were former socialist countries, many of which were members of the Warsaw Pact. Among the authors of the report, only the Polish expert represents the Central and Eastern European region.

The experts examined NATO's current situation and its future role. The Alliance will have to adapt to a more complex strategic environment over the next decade. This period is characterized by a return of geopolitical rivalry with Russia, the rise of China and the growing role of emerging and disruptive technologies, while also facing increased transnational threats and risks. Proposals were made to strengthen the Alliance's unity, solidarity, cohesion, and transatlantic bond, to enhance political consultation and coordination among Allies. NATO's political role and relevant instruments need to be strengthened to address threats and challenges to its security from any strategic direction [7]. 
The report compiled by the Reflection Group was handed over to the NATO Secretary General on November 25, 2020. A 67-page report entitled "NATO 2030: Unity for a New Era" was presented to NATO Foreign Ministers in early December 2020. The Report is divided into three parts: 1 . the vision and main findings; 2 . the security and political environment; 3 . recommendations. In total, the experts made 138 recommendations to decisionmakers [7].

In addition to preserving NATO's core tasks (collective defense, crisis management, maintaining defense capabilities, cooperative security), it is necessary to renew the 2010 Strategic Concept, taking into account changes in the geostrategic environment (confrontation with Russia, systematic rivalry with China). It has been stated that terrorism is one of the most immediate asymmetric threats, and the fight against terrorism should be one of NATO's main tasks. The Russian Federation is the main military threat for the next decade, so the dual-approach strategy (deterrence and dialogue) must be continued.

The Alliance needs to develop a political strategy towards China. It was proposed to set up a consultative body, where they can discuss NATO's security interests related to China, monitor the consequences of China's technological advance. In addition to effective nuclear deterrence, NATO has to strengthen support for arms control and address emerging and disruptive technologies. The report also addresses hybrid and cyber threats, outer space security in the transatlantic area and its peaceful use. Climate change is also shaping NATO's security environment; therefore experts recommend the creation of a Center of Excellence on Climate and Security.

\section{Recommendations on political cohesion and policy consultation}

A key chapter of the NATO 2030 report is "Recommendations: Strengthening
NATO's Role, Cohesion and Consultation", which covers political consultation between member countries, with the European Union as a key ally and with partner countries. Political unity and cohesion, transatlantic consultation, coordination of allied and national policies are recurring issues of the Alliance since 1956. NATO should therefore consider setting up a Center of Excellence for Democratic Resilience. The report calls for the strengthening of transatlantic consultation and the role of the North Atlantic Council. In order to improve NATO's effectiveness, experts have also touched on the Alliance's principles, which have been considered inviolable, including consensus-based decision-making, which is one of the cornerstones of the Alliance. The report proposed a restriction of the right of veto. Consideration could be given to setting up a more structured mechanism to allow the formation of voluntary ad-hoc coalitions within NATO so that the Alliance can/will remain active in the future even if not all members agree to each mission.

The proposal to form ad hoc coalitions is not a new phenomenon. There have already been serious debates within the Alliance about individual operations and the commitment of member states. In the wake of the Iraq war, an ad hoc "coalition of willingness", and in the case of air strikes in Libya, an ad hoc "coalition of capable" was formed. The first case involved countries wishing to participate in the operation and the latter countries that were capable to contribute to the operation.

\section{Political consultation with partners}

NATO's partnership initiatives (Partnership for Peace, Mediterranean Dialogue, Istanbul Cooperation Initiative, Partners Across the Globe) are key tools for building cooperative security and cooperation with partners. The third pillar of the political consultation is cooperation with current and future partner countries and initiatives. 
It would be a significant change if the Alliance changed the partnership frameworks and systems, which are typically organized on a geographical basis. NATO needs to review and intensify existing partnerships in order to move from the current demand-driven approach to the interest-driven approach. In the former case, partner countries determine the scope and depth of cooperation, in the latter NATO sets the priorities, based on its strategic needs and available resources for cooperation with partners.

This requires a well-thought-out partnership strategy, a global partnership plan and stable and predictable resources are needed for existing partnership initiatives and for possible new links. Both the Alliance and the partners need to clearly define mutual expectations and goals in order that regional partnership frameworks can operate and work effectively.

The relationship with Sweden and Finland can be a model for developing partnerships in other regions. On the one hand, the Alliance should deepen cooperation with partners in the Indian and Pacific regions (Australia, New Zealand, the Republic of Korea), and on the other hand should establish new partnerships with India [7].

According to Article 10 of the Washington Treaty, the Alliance is open to all European democracies that want to join and contribute to the security of the EuroAtlantic area. An open-door policy is a fundamental principle of NATO and is key to the integration of partners and preparation for their membership. Strengthening and expanding the partnership with Ukraine and Georgia is a strategic priority. Cooperation with Bosnia and Herzegovina needs to be stepped up in order to prevent destabilization in the Western Balkans. A recurring idea is to develop the Mediterranean Dialogue and the Istanbul Cooperation Initiative through increased political commitment, capacity and resilience building.
Due to the wide-ranging challenges from the southern region (climate change, illegal migration, scarcity of resources) and their geographical scope, the regional presence and cooperation with the African Union, the G5 Sahel and other multilateral organizations need to be strengthened.

Consideration should be given to setting up a Regional Center for the Mediterranean Dialogue, similar to the Regional Center in Kuwait of the Istanbul Cooperation Center.

According to the NATO 2030 report, the Alliance should focus on thematic-based collaborations rather than geographically organized and grouped partnership initiatives. Although this finding is seen as a new idea, a number of proposals have been made over the last decades to reshape partnership initiatives organized on a geographical basis. Security policy experts and the Alliance itself have made several attempts to organize partner countries effectively, and re-group them regionally $[8,9]$.

In April 2011, NATO Foreign Ministers adopted a new partnership policy, the socalled Berlin Partnership Package (BPP). Its main objective was a more effective and flexible partnership policy and the introduction of a single partnership instrument and framework. There has been a fundamental change of approach in partnership policy. Instead of "partner for membership" the "partner for partnership", approach was introduced, in addition to the importance of a value-based community, a cooperative approach to security has become a central issue. The new partnership policy has given existing and potential partners the opportunity to define their own relationship with the Alliance, the partnership activities they wish to engage in or initiate a dialogue with the NATO. Even then, the resources available for partnership programs made necessary to set priorities $[10,11]$.

A three-circle model was outlined in 2013 considering the effectiveness and flexibility of the Berlin Partnership Package. The partners were divided into three categories: 
1. Advanced Partners 2. Cooperation Partners and 3. Dialogue Countries. This allowed for wide-ranging cooperation with partners without geographical boundaries and previous partnership frameworks, common policy principles and values were not articulated as expectations [12]. In 2014, the Partnership Interoperability Initiative and the Interoperability Platform were adopted in the final declaration of the Wales Summit. Within the Interoperability Platform, Enhanced Partners are involved in operational planning, exercises, and regular policy consultations with the Alliance. The Defense and Related Security Capacity Building Initiative (DCBI) has been launched to support security sector reform and institution building, education and training [13].

\section{Conclusions}

The NATO 2030 report is essentially a comprehensive self-assessment process, a common forward thinking, a valuable summary. It has formulated a number of strategic tasks for the Alliance. Central to the report, one of the key strategic priorities is to adapt to new changes in the international environment, the need to develop strategic concept that reflect this, and its adoption at the next summit. It is also a guideline for the Alliance and the member states.

In the post bipolar era, NATO has continuously responded to changes in the security environment. In the 1990s, the focus was on cooperation with the Central and Eastern Europe countries and enlargement. From 2001, the focus was on the fight against terrorism, from 2014 on responses to the Russian challenge and strengthening collective defense. Today, the Alliance faces extremely diverse threats from many directions.

Since the foundation of the Alliance, maintaining political cohesion and unity has been an important strategic goal for member countries. The importance of transatlantic bond, consultation and consensus, as well as the need for concerted action, has recently been questioned, that is why the report makes proposals for a consultation mechanism of the Alliance. In order to improve NATO's effectiveness, experts have also touched upon inviolable principles. Restrictions on the right of veto have been formulated in relation to consensus-based decision-making.

The report focuses primarily on NATO's core tasks, with a particular focus on collective defense, with much less emphasis on projecting stability beyond the Alliance's area of responsibility. Strengthening NATO's role, cohesion and consultation chapter covers emerging and disruptive technologies, terrorism, traditional and emerging threats from the South, energy security, climate change and green defense, arms control and nuclear deterrence, human security, women, peace and security, epidemics and natural disasters, as well as hybrid and cyber threats and outer space [14].

The Alliance faces two challenges, Russia and China, due to the return of great power conflicts and the rivalry of geopolitical actors. Most probably Russia will remain the main military threat to NATO until 2030, that is why the Alliance must continue the dual-approach strategy of deterrence and dialogue. China will be of increasing importance in the period to 2030, so the Alliance needs to devote more time, resources and attention to China's security challenges. NATO has to have a political strategy, because China will be both an opportunity and a serious challenge in the next decade. But there is a difference on the assessment of the importance and role of China - a globally-minded America and a regionally focused Europe - so resolving this will be an important task for the future. The report covers three areas of political consultation: consultation among Allies, with the European Union and with partner countries. It could be a significant change if 
the Alliance changed the partnership frameworks, systems and initiatives, which are organized typically on a geographical basis. The focus will be on developing a global partnership plan, where more effective cooperation with countries of partnership initiatives is needed to advance NATO's strategic interests. Accordingly, NATO is moving from a demand-driven to an interestdriven approach. NATO sets priorities for cooperation with partners based on its strategic needs and available resources. This requires a well-thought-out partnership strategy in line with the new principles, as well as stable and predictable resources.

Experts conclude the report with a positive idea that if NATO moves from reflection to concrete practical steps, the Organization will remain the cornerstone of collective defense, and the guardian of peace and security. Developments and events in the coming decade will provide an answer to this.

\section{References List}

[1] The Future Tasks of the Alliance, Report of the Council -The Harmel Report, [02.16.2021] Available from: https://www.nato.int/cps/en/natohq/official_texts_26700.htm

[2] Szenes, Zoltán-Siposné Kecskeméthy, Klára: NATO 4.0 and Hungary; 20 years of membership, 30 years of cooperation, Budapest, Zrínyi Kiadó, 2019.

[3] Gates, Robert M.: Reflections on the status and future of the transatlantic alliance, [02.15.2021] Available from:

https://www.files.ethz.ch/isn/130842/GATES_Report_final.pdf

[4] Donald Trump on NATO, Turkey's Coup Attempt and the World, The New York Times, July 21, 2016. [02.26.2021] Available from:

https://www.nytimes.com/2016/07/22/us/politics/donald-trump-foreign-policyinterview.html

[5] Remarks by Donald Trump, President of the United States at the dedication of the 9/11\&Article 5 Memorial, [02.16.2021] Available from:

https://www.nato.int/nato_static_fl2014/assets/audio/audio_2017_05/20170525_170525 f.mp3

[6] The future of the EU, Emmanuel Macron warns Europe: NATO is becoming braindead. [02.16.2021] Available from:

https://www.economist.com/europe/2019/11/07/emmanuel-macron-warns-europe-natois-becoming-brain-dead

[7] NATO 2030: United for a new era. Analysis and recommendations of the Reflection Group appointed by the NATO Secretary General”, Brussels, 25 November 2020.

[8] Simon, Jeffrey: Partnership for Peace: Charting a Course for a New Era, Strategic Forum, March 2004. No. 206, pp. 1-14.

[9] Masala, Carlo-Saariluoma, Katariina: Renewing NATO's Partnerships: Towards a Coherent and Efficient Framework, NDC Forum Paper Series, June 2006. No 1. [02.26.2021] Available from: http://www.ndc.nato.int/download/publications/fp_01.pdf

[10] Active engagement in cooperative security: a more efficient and flexible partnership policy. [01.03. 2021] Available from:

http://www.nato.int/nato_static/assets/pdf/pdf_2011_04/20110415_110415-PartnershipPolicy.pdf

[11] Sipos Kecskeméthy, Klára: Milestones - NATO adaptation to changing security environments, Právo a bezpečnost', Ročník 2018. číslo 3. pp. 183-192. 
[12] Kamp, Karl-Heinz-Reisinger, Heidi: NATO’s partnership after 2014: Go West!, NDC Research Paper, 2013. No. 92. pp. 1-8.

[13] Wales Summit Declaration, Wales. 2014. [14.03.2021] Available from: http://www.nato.int/cps/en/natohq/official_texts_112964.htm

[14] Tardy, Thierry: "NATO 2030. United for a new era": a Digest, NDC Policy Brief, December 2020. No. 23. pp. 1-4. 